DOI: https://doi.org/10.18485/bells.2016.8.20

UDC: 821.111.09-31 Swift G.

\author{
Bojana Gledić \\ University of Belgrade \\ Faculty of Philology \\ Serbia
}

\title{
TRANSFORMATION OF BRITISHNESS - GRAHAM SWIFT AS A POSTCOLONIAL STORYTELLER
}

\begin{abstract}
According to some scholars, Graham Swift's opus falls under the category of postmodernism. Others, however, would more readily categorize his work as modernist fiction. Swift's choice of characters mainly does not reflect the contemporary changes in British demographics, and because of this it is not on first impulse that one would treat his work as postcolonial. However, using a broader definition of the term 'postcolonial' and leaning on certain aspects of the theories of Michel Foucault enable us to investigate Swift's work as that of a postcolonial storyteller. An encouragement on this path of investigation is his latest short story collection, aptly titled England and Other Stories (2014), from which two short stories will be examined: "Saving Grace" and "England".
\end{abstract}

Key words: Graham Swift, modernism, Post modernism, Postcolonial Literature, Britishness

E-mail address: bojanagledic@gmail.com 
Graham Swift (1949 - ) is a renowned contemporary British author. He has been writing novels, short stories and essays since the early eighties of the past century and has established a revered position in literary circles. One might argue that he is better known among literary critics than the wider audiences, but his novels have been translated into over thirty languages and a few have been made into motion pictures ("Waterland" in 1992, "Shuttlecock" in 1993 and "Last Orders" in 2001). Swift is the author of nine novels, two short story collections, one novella, Making an Elephant (a book of poetry and prose in connection with his profession of a writer) and numerous essays.

At this point in time Swift's writing career has spanned across a quarter of a century, as his first novel was published in 1980. As one can deduce, he is not as prolific a writer as some, but most of his novels were very wellreceived by literary critics and he is the recipient of numerous awards, such as the Guardian Fiction Award and the Geoffrey Faber Memorial Prize (both for Waterland). His most prestigious award, however, was the Booker prize for his 1996 novel Last Orders. Strangely, this is not the novel Swift is most famous for. He is most famous for Waterland (1983).

It is Waterland that perhaps best introduces the topics Swift most frequently deals with - the meaning of history, man's place in history and the role of history and legacy in the lives of the most ordinary of people. Swift's novels are usually set in a somewhat dreary atmosphere. In most of them you will read about a person who has an ancestor they are proud of, a person who, according to the protagonist, had found their place in history. Swift's protagonists, however, cannot seem to find their own identity or their own place in history (which is usually the period between post-WWII and the contemporary Britain of today). His characters come from different walks of life - one is a shop owner, one a history teacher, another an aerial photographer, one used to be a butcher (to name just a few) but the everyday struggles and dilemmas they are faced with are the same. Female characters are less prominent in Swift's work, but their role in the plot is usually crucial for the storyline.

If you wished to be more informed about the works of Graham Swift and looked him up in some more recent compendiums of literary reviews (in which he usually holds the place of an important contemporary British author) you would probably find him categorized as either a modernist or postmodernist author. In The Politics of Postmodernism, Linda Hutcheon describes Waterland as a "historiographic metafiction" (1991: 64). Because 
Bojana Gledić: Transformation of Britishness...

of the historiographic metafiction in Waterland, which is, as we mentioned, Swift's most famous novel, one may categorize him as a postmodern writer. However, some critics would not be as ready to categorize him as postmodernist. On the contrary, due to the narrative coherence present in most of his novels and the fact that they are taking place in the real world one may just as readily categorize Swift as a modernist writer (for example, such is the categorization by Malcolm Bradbury, who describes Swift's novels as having an echo of the Victorian novel and being 'modern social realism' (2001: 6)). Daniel Lea and Peter Widdowson, both authors of studies on Swift, recognize postmodern tendencies in Swift's work but would not strictly categorize Swift's work as such (Lea 2005: 6, Widdowson 2006: 4). Catherine Bernard, also a researcher of Swift's work, notices these opposing forces in his work, comparing them with the quiet but rebellious waters of the Fens in Waterland (1991: 8).

Whether one chooses to opt for either or both sides, an interesting point remains to be investigated. Graham Swift deals with the life of ordinary people - as we have already mentioned all his stories are about the lives of the "little people" - and all these people live in the UK after WWII. In spite of this, no one has ever tried to categorize Swift as a postcolonial writer. At first sight, this may seem logical, as he does not, strictly speaking, tackle topics in direct connection with the Empire, nor does he, on the other hand, present in his novels the numerous changes that have taken place in British demographics in the second half of the past century. However, if the UK has been the setting for numerous postcolonial voices in literature, voices given by second or third generation immigrant writers, then all literature produced in the UK following the fall of Empire could, in a way, be perceived as postcolonial. This, of course, depends on our definition of what the somewhat controversial term postcolonial refers to. Though perhaps its original meaning was in direct connection with the different colonies gaining independence, today it is closer to encompassing the cultural effects of colonization and/or its legacy. The point of contact has been irrevocably shifted to the former center after waves of immigrants from the former colonies flooded the British Isles following WWII. In fact, there is no point of contact per se any more because now the former colonial subjects are full citizens of the UK. However, invisible borders remain present among the population.

It is a well-known fact that there have been disputes over whether postcolonial literature should even exist as a separate line of study (for 
example, see Young's discussion on Ernst Gellner (2001: 5)). In addition to this, there have been disputes, among those who have accepted the existence of postcolonial literature, over what exactly can be considered to be such literature. We would most readily agree with the definitions provided by Ashcroft, Griffiths and Tiffin in their Key Concepts in Post-Colonial Studies (1998). They define postcolonialism as dealing “...with the effects ${ }^{1}$ of colonization on cultures and societies" (1998: 186) and postcolonial reading as "...reconsidering English literature and literary production as less a series of domestically inspired changes and progressions than one emanating from and through the imperial process and/or colonial contacts." (1998: 193) We would also agree with Ania Loomba when she says that "It is true that the term 'postcolonialism' has become so heterogeneous and diffuse that it is impossible to satisfactorily describe what its study might entail." (Loomba 1998: xii). This means that we would readily accept the fact that today, with the transformation of the world map, the metaphorical disappearance of borders and the constant migrations all literature written in the territory of former colonies or in the centres of former colonies, as the case is with British literature, could, in fact, be considered postcolonial. This would be postcolonial literature in a postcolonial Britain.

Graham Swift always boasts making up all his stories, claiming that there is absolutely nothing personal in them. In addition to this, he himself has said that the author and his biography do not matter, but that the moment in which the story is written, the time in history, is important (as per Gallix 2003: 10). This may be taken to imply, since he has been writing about the second half of the $20^{\text {th }}$ century, that the fact that this is the British postcolonial era the times had an effect on his choice of character and storyline. In addition to this, one gets the feeling, as one critic mentions, that when Swift's characters are described what he is in fact describing and discussing are aspects of the nation (Malcolm 2003: 21). Something that is instantly recognizable in Swift's fiction is the complete absence of the multicultural society the UK has become in the past decades. This could be a possible argument against investigating Swift's work in the postcolonial framework. However, as one critic mentions with regards to, for example, Last Orders, one could also argue that such is the characters' view of the world (Malcolm 2003: 19). People of different race do not interact in Swift's stories or do so on rare occasions.

\footnotetext{
1 Author's emphasis.
} 
Bojana Gledić: Transformation of Britishness...

To further sustain such a course of investigation, we would call upon the literary implications of some of the aspects of the theory of Michel Foucault. Firstly, the implication that one should always bear in mind that discourse is usually created in a pattern that has already been established and that everything (which includes literary works) should always be analyzed over and over again in a wider context. According to Foucault, there is no singular kind of an ideal discourse (Фуко 1998: 76). If we apply this aspect of his theory to the case of postcolonial literature, it becomes obvious that postcolonial discourse should, especially due to its diverse and controversial nature, constantly be re-examined within the set limits. Secondly, according to Foucault, in order to analyze relations of power, one must examine both sides (Fuko 2010: 388). This argument allows us to investigate the literature of a caucasian middle-aged Englishman who has lived in the United Kingdom all his life (and who writes about people who are similar to himself) in the postcolonial framework. Furthermore, according to Foucault, we always need to reinvestigate the existing categorizations in order to avoid creating unjustified positions of power for ourselves. If we readily dismiss Swift's literary world as having a slim chance of contributing to our understanding of what postcolonial implies, then what we are actually saying is that it is impossible for a writer of such a background and dealing with such topics to be a postcolonial writer, which is not necessarily true. Finally, according to Foucault, the role of the author in the creation of the text is to be ignored. The text itself is what matters, and it should not be dismissed on the grounds of the origin of the author. The author's biography, as Foucault claims, and as Swift himself has claimed, is irrelevant. If Graham Swift's texts can assist us in obtaining a clearer vision of what the contemporary British society is like, then they should be discussed within any discourse that allows this. Gaining insight into what it looks and feels like "on the other side" can sometimes be just as valuable as first-hand impressions of those who used to be behind this imaginary borderline.

The United Kingdom, as a powerful modern-day nation-state has gone through some incredible changes over the past few decades. After the fall of Empire, many aspects of life have become different both for the people of Great Britain and the people of the former colonies, whether they stayed in their homelands or found a new home in the former centre of the Empire. Due to these mass migrations, and due to second and further generations of former immigrants being born as British citizens, the issue of what it 
means to be British in the contemporary day and age remains a moot point. Unfortunately, the response from the local people has also remained ambiguous over the decades in spite of the numerous efforts to overcome differences among the population and to introduce multiculturality as a way of life. To sum up, the changes are there - they are clearly visible, but it is now up to the people to accept these changes and to start seeing their country, and the world, from a different perspective. To further illustrate this point, let us use Homi K. Bhabha's reflection on "the time of the nation" (Routledge 2000: 297):

...the people must be thought in a double-time; the people are the historical 'objects' of a nationalist pedagogy, giving the discourse an authority that is based on the pre-given or constituted historical origin or event; the people are also the 'subjects' of a process of signification that must erase any prior or originary presence of the nation-people to demonstrate the prodigious, living principle of the people as that continual process by which the national life is redeemed and signified as a repeating and reproductive process.

For all the above stated reasons, it is very interesting to investigate contemporary British literature in a postcolonial framework and to try to find the 'British' side of the story, and by 'British' in this case I mean what was traditionally considered to be 'British' in the pre-WWII period. It is even more interesting to investigate stories that do not directly address postimperial issues and seemingly have nothing to do with the fall of Empire. In the work of Graham Swift, there is an abundance of such cases. In 2014, as if to further support our idea about his work, Swift finally decided to tackle topics of multiculturality and did so in his collection of short stories aptly titled England and Other Stories. For the purpose of this paper, we have selected two stories to investigate, those titled "Saving Grace" and "England". The selection has been made according to their storylines, both are told by British men, but, as you shall see, they present the diversity the term British has come to mean today.

"Saving Grace" is a story about doctor Ranjit Shah, a Briton who has never visited the country of his origin, and his father's homeland - India. Doctor Shah is a heart doctor, so in this sense Swift perhaps wants to present him as someone being closer to getting to the human heart than the average person. This doctor loves to tell his patients stories. When 
Bojana Gledić: Transformation of Britishness...

he finishes giving them their diagnosis and prescriptions, before he says goodbye (hoping, as he says, never to see them again), he tells them the story of his father and of how he came to be. In the course of him telling his story, Swift plays with the contemporary British identity on a few occasions. First of all, when doctor Shah starts to tell his story, we can almost see the incredulous face of the listener who is looking at, as Swift says, a brown face: "Dr Shah had never ceased to tell the story. 'I'm as British as you are,' he might begin. 'I was born in Battersea.' Or, more challengingly: 'My mother is as white as you. You don't believe me?"' (Swift 2015: 85) Swift further tells us that at the beginning of the doctor's career, "even though by then the National Health had become awash (it was his own word) with black and brown faces, it was not uncommon for patients to cut up rough at being treated by an Asian, or an Asian-looking, doctor." (Swift 2015: 85) But now, as Swift says, "his seniority, his reputation as a top consultant and his winning smile usually banished any trouble" (Swift 2015: 85) Still, one can guess that the person sitting across the desk can be a bit baffled by the doctor claiming to be as British as them.

As he continues his story, Swift further plays with the main character's identity. Doctor Shah tells us that his father, whose name was also Ranjit, was from India, that he had belonged to that faction of the Indian people who supported the British rule, and that he fought on the side of the British during WWII. His father had first been deployed to Italy, but by a twist of fate he ended up in England where he fell in love, married a British woman and stayed there for the rest of his life. While telling his listener the first part of the story, doctor Shah says at one point: "The fact is I might have been Italian, I might be telling you this in Naples or Rome. Think of that." (Swift 2015: 87) So, wherever his father's ship may have landed, this would have been the identity his son would have taken, which is a very interesting take on nationality, but a reality that the modern world is facing at a time when thousands of people from other parts of the world are coming to Europe, hoping that one day their children may be Europeans. To his own mind, doctor Shah has no questions regarding his identity; when he tells his listener that his father was born in India, in Poona, in 1925, he adds "In those days of course the British ruled. We ruled." (Swift 2015: 86)

Further on, as the doctor tells his story, it seems that he is very pleased with the story of his family and that he loves to tell it. We learn that his father took part in D-Day, as one of the rare Indians who did so, and he ended up in a British hospital as a wounded soldier. He was severely 
injured, and he would have lost a leg had it not been for another Indian man who had come from Bombay to serve the British in a medical capacity. Because of doctor Chaudhry's origin, Ranjit was the only wounded soldier who accepted the young doctor's alternative treatment and that saved his leg. It also was there, in the hospital, that he met Rosie Watts, a British nurse, and they decided to get married, "against all the odds" (Swift 2015: 87). At this point in the story Swift, in his indirect manner, informs the reader of what a strange and unexpected turn of events this was: "Imagine it. London, Battersea. At the end of the war. Against all the odds. But my mother always said there were no two ways about it. Ranjit was the one. And if she could fall in love with a man with his body all smashed up and the possibility that he'd lose a leg, then wasn't that a pretty good test of love? Setting aside the other matter that had nothing to do with the war ${ }^{2}$." (Swift 2015: 91) The doctor's father never managed to return to India and see his family, but he was content because he believed that he had done well and made his family proud by marrying a British lady and settling in the country they loved so much.

As the story unfolds, we learn that the doctor was very close with his father and that he made his father very proud by becoming a doctor. His father was aware of the choice he and his wife had made, so he made sure to teach his son that he should never feel disadvantaged in life. To prove his point, he showed his son an old photograph from the hospital, of three men who had lost a leg, but were smiling nevertheless, and told him that if he should ever feel disadvantaged he should remember the men in the photograph. Even though he was a small boy at the time, he remembered this clearly. He dedicated his entire life to making his father proud in spite of the 'disadvantage' he was unfortunately aware of. In fact, he became so successful, that when he mentions this part of the story "Dr Shah's smile would broaden again and his listener might think - as he or she was perhaps meant to think - that 'disadvantaged' sat strangely on the lips of a senior consultant in an expensive pinstriped suit." (Swift 2015: 89)

In the doctor's story we also learn that his father passed away and we find out that for doctor Shah his father always represented India and he always kept an unconscious bond with his father's homeland throughout his life. With his father's death, it was as if the doctor had lost India too. In his father's final moments "He'd held him close and had the fleeting bizarre thought that he was also holding India." (Swift 2015: 86) So, even though

2 Author's emphasis. 
Bojana Gledić: Transformation of Britishness...

this thought is strange, because the doctor has never been to India, and apparently never thinks of India, at the moment his father dies, he thinks of a story his father has told him and of India "as it had once appeared in old school atlases, in the 1950s, blush-red and plumply dangling, not unlike some other familiar shape." (Swift 2015: 93) The doctor is certain of who he is, but it appears that India and the memories of his father will never leave his heart.

The main protagonist of "England" is also a Briton, but one that is instantly recognizable as such. And even though, at first sight, he has not had much contact with anything in connection with the Empire, as the story develops we realize that this is not quite true. The man's name is Kenneth Black and he lives on 'the edge of England' with his wife Ruth. We learn that he works as a coastguard and that he is not familiar with much more than his immediate surroundings. He has not visited many places, and he has gone to London only twice. Nevertheless, he seems to be satisfied with his life. We find out that he both loves and admires his country, and that he even finds seeing the same scenery every morning when he goes to work inspirational: "He told himself, routinely, not to take it for granted." (Swift 2015: 257) We also find out that he has always wanted to be a coastguard, but he admits to himself that he was not courageous enough to be anything more. He wanted to protect his country, but always coveted the same level of safety for himself. When he talks about his job, we get a glimpse of the past 'glory' of a vast Empire: "Ships, he knew, had once sailed up the Bristol Channel with cargoes of sugar. On the way out they'd made for Africa. Then sailed west." (Swift 2015: 273) Today, naturally, there is not much of this glory left, except in these echoes of the past. One might even deduce that the man had selected such a job in the aftermath of such a glorious past, thinking that he would continue guarding the greatness against an unknown enemy. At the end of the story we find Kenneth "on the edge of England, supposedly guarding it, looking outwards." (Swift 2015: 274) but instead of being certain what his exact role is he realizes that he actually knows very little about his country. An interesting episode in the life of this man had brought about such sentiments.

One morning, as he was driving to work at the crack of dawn he was surprised to find a car standing in the middle of the road with its wheels lodged in a gully. Being a coastguard, he immediately felt the need to assist anyone who might be in trouble, so he stopped his car. His reaction upon seeing the distressed man was close to incredulity because what he saw was 
a black face; "You might say it wasn't deep black, as black faces go, but it was black. This was not a place, an area, for black faces. It was remarkable to see them." (Swift 2015: 259) Kenneth is so surprised that he almost does not know how to respond. Soon enough, however, he encounters a different problem - the man seems to be speaking in different voices and different accents and Kenneth does not know what to make of it. "The first voice (the normal one?) had a strong accent which, nonetheless, he couldn't place, because all northern accents eluded him. The second voice was a foreign voice in the sense that the accent wasn't English at all. He couldn't place it exactly either, just that it was broadly - very broadly Caribbean." (Swift 2015: 259)

The coastguard continues to be baffled by the strange man's behaviour. He sees that he is driving a blue BMW, albeit a vintage one, not very expensive. Kenneth also realizes, because of a blanket and pillow on the back seat, that the man could be spending his nights in the car. As the stranger tries to explain how he has found himself stuck in the middle of nowhere, he keeps changing voices and accents and at one point Kenneth even attempts to calm him down, with little success. The man mentions almost hitting a deer, "'A lee-tal baby Bambee."' (Swift 2015: 261) and Kenneth does not know whether to believe him because he has never seen a deer in those parts just standing in the middle of the road, at the same time asking himself whether he would believe the story if the stranger were someone else. Ultimately, something about the man makes him feel protective and he decides to help him in the end. Together, they manage to pull the car out of the ditch, thus enabling the stranger to safely continue his journey. In the process Kenneth learns that the man is from Yorkshire (Leeds) and that he is a travelling comedian whose name is Johnny Dewhurst and who is on his way to Barnstaple, Ilfracombe, just one of the stops on his tour of England. They end up having coffee together and after saying their goodbyes they each go their separate ways but Kenneth cannot stop thinking about the man and his amazing way of life - constantly being on the road, seeing all the amazing places England has to offer. For a moment it even appears as if Kenneth were jealous of the man.

On a few occasions throughout telling the story Swift tries to convey to the reader just how strange the whole encounter is to a man like Kenneth. Aside from being shocked upon seeing a black face on Exmoor, for a moment Johnny's leather jacket looks to Kenneth "like a droopy black second skin, which was an unfortunate way of thinking of it." (Swift 2015: 
Bojana Gledić: Transformation of Britishness...

264) Kenneth is also surprised by the man's slight build, which draws upon stereotypes. On the other hand, as strange as the man may seem to him, Kenneth realizes his difficult position in the contemporary British society: "The man was behaving, it was true, as if he were being doubted, were under suspicion, as if this were a familiar situation." (Swift 2015: 262) While they are having coffee together Kenneth is reluctant to tell the man that his last name is Black because he is afraid that he might insult him. Johnny, on the other hand, cracks a joke about his own appearance while they are having the coffee "I never know whether to make a joke. And I never know whether to make a joke out of the black or the coffee. See my face, man? Black or coffee?"' (Swift 2015: 267)

As the story of this strange encounter draws to a close, we realize that Johnny Dewhurst, who is making ends meet trying to make people laugh may in fact be more at home in England than the man supposedly guarding it. As the story ends, Kenneth seems to be in two minds about the choices he has made in life and wonders what it must be like to be a man like Johnny. He realizes that there seems to be a whole world he had been oblivious to: "He knew what he knew about this land to which his back was largely turned, this strange expanse beyond Exmoor, but it was precious little really. He really knew, he thought, as he brought his car to a halt again, nothing about it at all." (Swift 2015: 274)

This brief exploration of the storylines of these two short stories offers a good start for the further investigation of Graham Swift's opus in a different framework, that of postcolonial literature. Life in these modern times of great migrations may be complicated, especially in multicultural nations such as the British one, but at times precious works of literary art may assist us in gaining a clearer insight into and understanding of such environments. There is no better way to become acquainted with the complexities of a certain society than by reading the literary production of individuals coming from it. Furthermore, understanding the complexities and challenges of a multicultural society helps us to understand ourselves better, as citizens of the world. After all, as Salman Rushdie wrote in his Imaginary Homelands "It may be argued that the past is a country from which we have all emigrated, that its loss is a part of our common humanity." (Rushdie 2010: 12) 


\section{References}

Ashcroft, B, G. Griffiths and H. Tiffin. (1998). Key Concepts in Post-Colonial Studies. London: Routledge.

Bernard, C. (1991). Graham Swift : la parole chronique. Nouveaux échos de la fiction britannique. Nancy: Presses universitaires de Nancy.

Bhabha, H. K. (ed.). (2000). Nation and Narration. London: Routledge.

Bradbury, M. (2001). The Modern British Novel 1878-2001. London: Penguin.

Фуко, М. (1998). Археологија знаньа, прев. Младен Козомара. Београд: Плато. Fuko, M. (2010). Spisi i razgovori, prev. Ivan Milenković. Beograd: Fedon. Gallix, F. (2003). Écrire l'imagination. Bordeaux: Presses universitaires.

Hutcheon, L. (1991). The Politics of Postmodernism. New York \& London: Routledge.

Lea, D. (2005). Graham Swift. Manchester: Manchester University Press. Loomba, A. (1998). Colonialism / Postcolonialism. London: Routledge.

Malcolm, D. (2003). Understanding Graham Swift. South Carolina: University of South Carolina Press.

Rushdie, S. (2010). Imaginary Homelands. London: Vintage Books.

Swift, G. (2015). England and Other Stories. London: Scribner.

Widdowson, P. (2006). Graham Swift. United Kingdom: Northcote House Publishers, Ltd. 